\title{
Global Food Security: Challenges and Policies
}

\author{
Mark W. Rosegrant* and Sarah A. Cline
}

\begin{abstract}
Global food security will remain a worldwide concern for the next 50 years and beyond. Recently, crop yield has fallen in many areas because of declining investments in research and infrastructure, as well as increasing water scarcity. Climate change and HIV/AIDS are also crucial factors affecting food security in many regions. Although agroecological approaches offer some promise for improving yields, food security in developing countries could be substantially improved by increased investment and policy reforms.
\end{abstract}

The ability of agriculture to support growing populations has been a concern for generations and continues to be high on the global policy agenda. The eradication of poverty and hunger was included as one of the United Nations Millennium Development Goals adopted in 2000. One of the targets of the Goals is to halve the proportion of people who suffer from hunger between 1990 and 2015 (1). Meeting this food security goal will be a major challenge. Predictions of food security outcomes have been a part of the policy landscape since Malthus' An Essay on the Principle of Population of 1798 (2). Over the past several decades, some experts have expressed concern about the ability of agricultural production to keep up with global food demands (3-5), whereas others have forecast that technological advances or expansions of cultivated area would boost production sufficiently to meet rising demands (6-8). So far, dire predictions of a global food security catastrophe have been unfounded.

Nevertheless, crop yield growth has slowed in much of the world because of declining investments in agricultural research, irrigation, and rural infrastructure and increasing water scarcity. New challenges to food security are posed by climate change and the morbidity and mortality of human immunodeficiency virus/acquired immunodeficiency syndrome (HIV/AIDS). Many studies predict that world food supply will not be adversely affected by moderate climate change, by assuming farmers will take adequate steps to adjust to climate change and that additional $\mathrm{CO}_{2}$ will increase yields (9). However, many developing countries are likely to fare badly. In warmer or tropical environments, climate change may result in more intense rainfall events between prolonged dry periods, as well as reduced or more variable water resources for irrigation. Such conditions may promote pests and disease on crops and livestock, as well as soil

International Food Policy Research Institute, $2033 \mathrm{~K}$ Street, N.W., Washington, DC 20006, USA.

*To whom correspondence should be addressed. Email: m.rosegrant@cgiar.org erosion and desertification. Increasing development into marginal lands may in turn put these areas at greater risk of environmental degradation $(10,11)$. The HIV/AIDS epidemic is another global concern, with an estimated 42 million cases worldwide at the end of 2002 (12); 95\% of those are in developing countries. In addition to its direct health, economic, and social impacts, the disease also affects food security and nutrition. Adult labor is often removed from affected households, and these households will have less capacity to produce or buy food, as assets are often depleted for medical or funeral costs (13). The agricultural knowledge base will deteriorate as individuals with farming and science experience succumb to the disease (14). Can food security goals be met in the face of these old and new challenges?

Several organizations have developed quantitative models that project global food supply and demand into the future (15-19). According to the most recent baseline projections of the International Food Policy Research Institute's (IFPRI's) International Model for Policy Analysis of Agricultural Commodities and Trade (IMPACT) (20), global cereal production is estimated to increase by $56 \%$ between 1997 and 2050, and livestock production by $90 \%$. Developing countries will account for $93 \%$ of cerealdemand growth and $85 \%$ of meat-demand growth to 2050 . Income growth and rapid urbanization are major forces driving increased demand for higher valued commodities, such as meats, fruits, and vegetables. International agricultural trade will increase substantially, with developing countries' cereal imports doubling by 2025 and tripling by 2050. Child malnutrition will persist in many developing countries, although overall, the share of malnourished children is projected to decline from $31 \%$ in 1997 to $14 \%$ in 2050 (Fig. 1). Nevertheless, this represents a nearly 35-year delay in meeting the Millennium Development Goals. In some places, circumstances will deteriorate, and in sub-Saharan Africa, the number of malnourished preschool children will increase between 1997 and 2015, after which they will only decrease slightly until 2050. South Asia is another region of concern - although progress is expected in this region, more than $30 \%$ of preschool children will remain malnourished by 2030 , and $24 \%$ by $2050(21)$.

Achieving food security needs policy and investment reforms on multiple fronts, including human resources, agricultural research, rural infrastructure, water resources, and farm- and community-based agricultural and natural resources management. Progressive policy action must not only increase agricultural production, but also boost incomes and reduce poverty in rural areas where most of the poor live. If we take such an approach, we can expect production between 1997 and 2050 to increase by $71 \%$ for cereals and by $131 \%$ for meats. A reduction in childhood malnutrition would follow; the number of malnourished children would decline from 33 million in 1997 to 16 million in 2050 in sub-Saharan Africa, and from 85 million to 19 million in South Asia (Fig. 1).

Increased investment in people is essential to accelerate food security improvements. In agricultural areas, education works directly to enhance the ability of farmers to adopt more

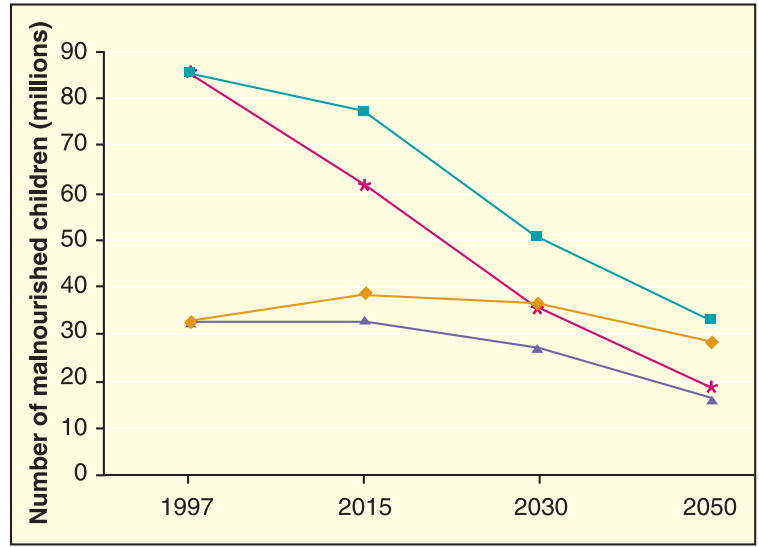

Fig. 1. Projected number of malnourished children in South Asia and sub-Saharan Africa under baseline and progressive policy actions scenarios, 1997 to 2050. Blue-green squares, South Asia, baseline scenario; red asterisks, South Asia, progressive policy actions scenario; yellow diamonds, sub-Saharan Africa, baseline scenario; purple triangles, sub-Saharan Africa, progressive policy actions scenario. Source: International Food Policy Research Institute (21). 
advanced technologies and crop-management techniques and to achieve higher rates of return on land (22). Moreover, education encourages movement into more remunerative nonfarm work, thus increasing household income. Women's education affects nearly every dimension of development, from lowering fertility rates to raising productivity and improving environmental management (23). Research in Brazil shows that $25 \%$ of children were stunted if their mothers had four or fewer years of schooling; however, this figure fell to $15 \%$ if the mothers had a primary education and to $3 \%$ if mothers had any secondary education (24). Poverty reduction is usually enhanced by an increase in the proportion of educational resources going to primary education and to the poorest groups or regions (25-27). Investments in health and nutrition, including safe drinking water, improved sewage disposal, immunization, and public health services, also contribute to poverty reduction. For example, a study in Ethiopia shows that the distance to a water source, as well as nutrition and morbidity, all affect agricultural productivity of households (28).

When rural infrastructure has deteriorated or is nonexistent, the cost of marketing farm produce, and thus escaping subsistence agriculture and improving incomes, can be prohibitive for poor farmers. Rural roads increase agricultural production by bringing new land into cultivation and by intensifying existing land use, as well as consolidating the links between agricultural and nonagricultural activities within rural areas and between rural and urban areas (29). Government expenditure on roads is the most important factor in poverty alleviation in rural areas of India and China, because it leads to new employment opportunities, higher wages, and increased productivity $(30,31)$.

In addition to being a primary source of crop and livestock improvement, investment in agricultural research has high economic rates of return (32). Three major yield-enhancing strategies include research to increase the harvest index (33), plant biomass, and stress tolerance (particularly drought resistance) $(34,35)$. For example, the hybrid "New Rice for Africa," which was bred to grow in the uplands of West Africa, produces more than $50 \%$ more grain than current varieties when cultivated in traditional rainfed systems without fertilizer. Moreover, this variety matures 30 to 50 days earlier than current varieties and has enhanced disease and drought tolerance (36). In addition to conventional breeding, recent developments in nonconventional breeding, such as marker-assisted selection and cell and tissue culture techniques, could be employed for crops in developing countries, even if these countries stop short of transgenic breeding. To date, however, appli- cation of molecular biotechnology has been mostly limited to a small number of traits of interest to commercial farmers, mainly developed by a few global life science companies.

Although much of the science and many of the tools and intermediate products of biotechnology are transferable to solve highpriority problems in the tropics and subtropics, it is generally agreed that the private sector will not invest sufficiently to make the needed adaptations in these regions with limited market potential. Consequently, the public sector will have to play a key role, much of it by accessing proprietary tools and products from the private sector (37).

Irrigation is the largest water user worldwide, but also the first sector to lose out as scarcity increases (38). The challenges of water scarcity are heightened by the increasing costs of developing new water sources, soil degradation in irrigated areas, groundwater depletion, water pollution, and ecosystem degradation. Wasteful use of already developed water supplies may be encouraged by subsidies and distorted incentives that influence water use. Hence, investment is needed to develop new water management policies and infrastructure. Although the economic and environmental costs of irrigation make many investments unprofitable, much could be achieved by water conservation and increased efficiency in existing systems and by increased crop productivity per unit of water used. Regardless, more research and policy efforts need to be focused on rainfed agriculture. Exploiting the full potential of rainfed agriculture will require investment in water harvesting technologies, crop breeding, and extension services, as well as good access to markets, credit, and supplies. Water harvesting and conservation techniques are particularly promising for the semi-arid tropics of Asia and Africa, where agricultural growth has been less than $1 \%$ in recent years. For example, water harvesting trials in Burkina Faso, Kenya, Niger, Sudan, and Tanzania show increases in yield of a factor of 2 to 3 , compared with dryland farming systems $(39,40)$.

Agroecological approaches that seek to manage landscapes for both agricultural production and ecosystem services are another way of improving agricultural productivity. A study of 45 projects, using agroecological approaches, in 17 African countries shows cereal yield improvements of 50 to 100 percent (41). There are many concomitant benefits to such approaches, as they reduce pollution through alternative methods of nutrient and pest management, create biodiversity reserves, and enhance habitat quality through careful management of soil, water, and natural vegetation. Important issues remain about how to scale up agroecological approaches. Pilot programs are needed to work out how to mobilize private investment and to develop systems for payment of ecosys- tem services. All of these issues require investment in research, system development, and knowledge sharing.

To implement agricultural innovation, we need collective action at the local level, as well as the participation of government and nongovernmental organizations that work at the community level. There have been several successful programs, including those that use water harvesting and conservation techniques $(42,43)$. Another priority is participatory plant breeding for yield increases in rainfed agrosystems, particularly in dry and remote areas. Farmer participation can be used in the very early stages of breed selection to help find crops suited to a multitude of environments and farmer preferences. It may be the only feasible route for crop breeding in remote regions, where a high level of crop diversity is required within the same farm, or for minor crops that are neglected by formal breeding programs $(44,45)$.

Making substantial progress in improving food security will be difficult, and it does mean reform of currently accepted agricultural practices. However, innovations in agroecological approaches and crop breeding have brought some documented successes. Together with investment in research and water and transport infrastructure, we can make major improvements to global food security, especially for the rural poor.

\section{References}

1. The World Bank Group, "Millennium Development Goals: About the Goals," www.developmentgoals. org/About_the_goals.htm (2003).

2. T. R. Malthus, An Essay on the Principle of Population (Norton, New York, 2003).

3. P. R. Ehrlich, A. H. Ehrlich, The Population Explosion (Simon \& Schuster, New York, 1990).

4. L. Brown, H. Kane, Full House: Reassessing the Earth's Population Carrying Capacity (Norton, New York, 1994).

5. D. H. Meadows, D. L. Meadows, J. Randers, Beyond the Limits: Confronting Global Collapse, Envisioning a Sustainable Future (Chelsea Green, White River Junction, VT, 1992).

6. E. Boserup, The Conditions of Agricultural Growth: The Economics of Agrarian Change Under Population Pressure (Aldine, Chicago, 1965).

7. C. Clark, Starvation or Plenty (Taplinger, New York, 1970).

8. J. L. Simon, The Ultimate Resource 2 (Princeton Univ. Press, Princeton, NJ, 1998).

9. R. M. Adams, B. H. Hurd, Choices 14, 22 (1999).

10. T. E. Downing, Renewable Energy 3, 491 (1993).

11. International Panel on Climate Change, Climate Change 2001: Impacts, Adaptation, and Vulnerability (Cambridge Univ. Press, Cambridge, 2001).

12. Joint United Nations Program on HIVIAIDS (UNAIDS), www.unaids.org (2003).

13. Food and Agricultural Organization of the United Nations (FAO), "The impact of HIV/AIDS on food security," Committee on World Food Security, 27th Session, Rome, 28 May to 1 June, 2001.

14. L. Haddad, S. Gillespie, J. Int. Dev. 13, 487 (2001).

15. J. Bruinsma, Ed., World Agriculture: Towards 2015/ 2030: An FAO Study (Earthscan, London, 2003).

16. Food and Agricultural Policy Research Institute, U.S. and World Agricultural Outlook 2003 (Staff Report 1-03, Food and Agricultural Policy Research Institute, University of lowa and University of Missouri-Columbia, 2003).

17. M. W. Rosegrant, M. Paisner, S. Meijer, J. Whitcover, Global Food Projections to 2020: Emerging Trends and Alternative Futures (IFPRI, Washington, DC, 2001).

18. Organisation for Economic Co-operation and Development, Agricultural Outlook 2003-2008 (Organisa- 
tion for Economic Co-operation and Development, Paris, 2003).

19. U.S. Department of Agriculture, Office of the Chief Economist, USDA Agricultural Baseline Projections to 2012 (Staff Report WAOB-2003-1, U.S. Department of Agriculture, Washington, DC, 2003).

20. M. W. Rosegrant, S. Meijer, S. A. Cline, "International Model for Policy Analysis of Agricultural Commodities and Trade (IMPACT): Model description" (IFPRI, Washington, DC, 2002), available at www.ifpri.org/themes/impact/impactmodel.pdf.

21. International Food Policy Research Institute, unpublished data.

22. World Bank, Poverty: World Development Indicators (Oxford Univ. Press, New York, 1990).

23. World Bank, Poverty Reduction and the World Bank: Progress and Challenges in the 1990s (The International Bank for Reconstruction and Development/The World Bank, Washington, DC, 1996).

24. A. Kassouf, B. Senauer, Econ. Dev. Cult. Change 44 817 (1996).

25. M. Lipton, S. Yaqub, E. Darbellay, Success in AntiPoverty (International Labour Office, Geneva, 1998).

26. R. Gaiha, Design of Poverty Alleviation Strategy in Rural Areas (FAO, Rome, 1994).

27. R. Singh, P. Hazell, Econ. Polit. Wkly. 28, A9 (20 March 1993).

28. A. Croppenstedt, C. Muller, Econ. Dev. Cult. Change 48, 475 (2000).
29. International Fund for Agricultural Development (IFAD), The State of World Rural Poverty: A Profile of Asia (IFAD, Rome, 1995).

30. S. Fan, P. Hazell, S. Thorat, Am. J. Agric. Econ. 82 , 1038 (2000).

31. S. Fan, L. Zhang, X. Zhang, "Growth, inequality, and poverty in rural China: The role of public investments" (IFPRI Research Report 125, IFPRI, Washington, DC, 2002)

32. J. M. Alston, P. G. Pardey, C. Chan-Kang, T. J. Wyatt, M. C. Marra, "A meta-analysis of rates of return to agricultural R\&D: Ex pede Herculem?" (IFPRI Research Report 113, IFPRI, Washington, DC 2000).

33. The harvest index is defined as "the ratio of grain to total crop biomass" (34).

34. K. G. Cassman, Proc. Natl. Acad. Sci. U.S.A. 96, 5952 (1999).

35. L. T. Evans, Feeding the Ten Billion: Plants and Population Growth (Cambridge Univ. Press, Cambridge, 1998)

36. West Africa Rice Development Association, "Consortium formed to rapidly disseminate New Rice for Africa," available at www.warda.org/warda1/ main/newsrelease/newsrel-consortiumapr01.htm [cited 2000]

37. D. Byerlee, K. Fischer, "Accessing modern science: Policy and institutional options for agricultural biotechnology in developing countries" (Agricultural
Knowledge and Information Systems Discussion Paper, The World Bank, Washington, DC, 2000).

38. M. W. Rosegrant, X. Cai, S. A. Cline, World Water and Food to 2025: Dealing with Scarcity (IFPRI, Washington, DC, 2002).

39. S. M. Barghouti, Sustain. Dev. Int. 1, 127 (2001), www.sustdev.org/agriculture/articles/edition $1 / 01$. 127.pdf.

40. Food and Agriculture Organization of the United Nations, Crops and Drops (FAO, Rome, 2000).

41. J. Pretty, Environ. Dev. Sustain. 1, 253 (1999)

42. J. Pretty, World Dev. 23, 1247 (1995).

43. T. Oweis, A. Hachum, J. Kijne, "Water harvesting and supplementary irrigation for improved water use efficiency in dry areas" (System-Wide Initiative on Water Management Paper 7, International Water Management Institute, Colombo, Sri Lanka, 1999).

44. S. Ceccarelli, S. Grando, R. H. Booth, in Participatory Plant Breeding, P. Eyzaguire, M. Iwanaga, Eds. (International Plant Genetics Research Institute, Rome, 1996), pp. 99-116.

45. J. Kornegay, J. A. Beltran, J. Ashby, in Participatory Plant Breeding, P. Eyzaguire, M. Iwanaga, Eds. (International Plant Genetics Research Institute, Rome, 1996), pp. 151-159.

Web Resources

www.sciencemag.org/cgi/content/full/302/5652/1917/ DC1

VIE WPOINT

\title{
New Visions for Addressing Sustainability
}

\author{
A. J. McMichael, ${ }^{1 *}$ C. D. Butler, ${ }^{1}$ Carl Folke ${ }^{2}$
}

\begin{abstract}
Attaining sustainability will require concerted interactive efforts among disciplines, many of which have not yet recognized, and internalized, the relevance of environmental issues to their main intellectual discourse. The inability of key scientific disciplines to engage interactively is an obstacle to the actual attainment of sustainability. For example, in the list of Millennium Development Goals from the United Nations World Summit on Sustainable Development, Johannesburg, 2002, the seventh of the eight goals, to "ensure environmental sustainability," is presented separately from the parallel goals of reducing fertility and poverty, improving gains in equity, improving material conditions, and enhancing population health. A more integrated and consilient approach to sustainability is urgently needed.
\end{abstract}

For human populations, sustainability means transforming our ways of living to maximize the chances that environmental and social conditions will indefinitely support human security, wellbeing, and health. In particular, the flow of nonsubstitutable goods and services from ecosystems must be sustained. The contemporary stimulus for exploring sustainability is the accruing evidence that humankind is jeopardizing its own longer term interests by living beyond Earth's means, thereby changing atmospheric composition and depleting biodiversity, soil fertility, ocean fisheries, and freshwater supplies (1).

Much early discussion about sustainability has focused on readily measurable intermediate outcomes such as increased economic perfor-

${ }^{1}$ National Centre for Epidemiology and Population Health, Australian National University, Canberra, ACT 0200, Australia. 2Department of Systems Ecology, Stockholm University, Stockholm, Sweden.

*To whom correspondence should be addressed. Email: tony.mcmichael@anu.edu.au mance, greater energy efficiency, better urban design, improved transport systems, better conservation of recreational amenities, and so on. However, such changes in technologies, behaviors, amenities, and equity are only the means to attaining desired human experiential outcomes, including autonomy, opportunity, security, and health. These are the true ends of sustainability - and there has been some recognition that their attainment, and their sharing, will be optimized by reducing the rich-poor divide (2).

Some reasons for the failure to achieve a collective vision of how to attain sustainability lie in the limitations of, and disjunction between, disciplines we think should be central to our understanding of sustainability: demography, economics, ecology, and epidemiology. These disciplines bear on the size and economic activities of the human population, how the population relates to the natural world, and the health consequences of ecologically injudicious behavior. Sustainability issues are of course not limited to these four disciplines, but require the engagement and inter- disciplinary collaboration of other social and natural sciences, engineering, and the humanities (3).

Neither mainstream demography nor economics, for the most part, incorporates sufficient appreciation of environmental criticalities into their thinking. They implictly assume that the world is an open, steady-state system within which discipline-specific processes can be studied. Although contemporary ecology has broadened its perspectives significantly, there is a tendency to exclude consideration of both human influence and dependence on ecosystem composition, development, and dynamics. Epidemiologists focus mainly on individual-level behaviors and circumstances as causes of disease. This discounts the underlying social, cultural, and political determinants of the distribution of disease risk within and between populations, and has barely recognized the health risks posed by today's global environmental changes.

These four disciplines share a limited ability to appreciate that the fate of human populations depends on the biosphere's capacity to provide a continued flow of goods and services. The assumption of human separateness from the natural world perpetuates a long-standing, biblically based premise of Western scientific thought of Man as master, with dominion over Nature (4). Many disciplines still apply world views that predate current understanding of complex system dynamics and of how human evolutionary history has developed with, and helped shape, 